\title{
Growth hormone treatment of Canadian children: results from the GeNeSIS phase IV prospective observational study
}

\author{
Cheri Deal PhD MD, Susan Kirsch MD, Jean-Pierre Chanoine MD PhD, Sarah Lawrence MD, \\ Elizabeth Cummings MD, Elizabeth T. Rosolowsky MD MPH, Seth D. Marks MD MSc, Nan Jia PhD, \\ Christopher J. Child PhD; for the GeNeSIS National Board on behalf of the GeNeSIS Canada \\ Investigators*
}

\section{Abstract}

Background: Country-specific data on outcomes of treatment with recombinant human growth hormone are lacking. We present such data for children treated with growth hormone in Canada.

Methods: We describe characteristics and outcomes of 850 children (mean age at baseline 8.5 yr) treated with growth hormone constituting the Canadian cohort of the multinational phase IV prospective observational Genetics and Neuroendocrinology of Shortstature International Study (GeNeSIS). The diagnosis associated with short stature was as determined by the investigator. Auxological data were evaluated yearly until near-adult height. Adverse events were assessed in all growth-hormone-treated patients.

Results: The diagnosis ascribed as the cause of short stature was growth hormone deficiency in 526 children (61.9\%), predominantly organic rather than idiopathic, particularly congenital pituitary abnormalities and intracranial tumours. All diagnostic groups with sufficient patients for analysis had increased height velocity standard deviation score (SDS) and height SDS during growth hormone treatment. For patients who reached near-adult height $(n=293)$, the mean height SDS was within the normal range for about $80 \%$ of patients with organic growth hormone deficiency $(n=131)$ or idiopathic growth hormone deficiency $(n=50), 50 \%$ of patients with idiopathic short stature $(n=10)$ and $46 \%$ of patients with Turner syndrome $(n=79)$. Eleven deaths were reported, 7 in patients with organic growth hormone deficiency. Serious adverse events considered related to growth hormone treatment $(n=19)$ were isolated except for medulloblastoma recurrence $(n=2)$ and adenoidal hypertrophy $(n=2)$.

Interpretation: Growth hormone treatment was effective and had a good safety profile in Canadian children. Growth hormone dosages were lower than in the US and global GeNeSIS cohorts, and a greater proportion of treated Canadian children had organic growth hormone deficiency. Study registration: ClinicalTrials.gov, no. NCT01088412.

hildren with short stature and/or growth failure may benefit from growth hormone treatment to increase adult height. ${ }^{1}$ Recombinant human growth hormone was initially approved for growth hormone deficiency, which remains the main indication and can be due to congenital or acquired causes. ${ }^{2,3}$ Pediatric growth hormone therapy has been approved in many countries for additional conditions, including Turner syndrome, Prader-Willi syndrome, chronic renal insufficiency, short stature homeoboxcontaining gene (SHOX) deficiency, Noonan syndrome and idiopathic short stature, as well as for children born small for gestational age. ${ }^{1,-11}$ For approved indications and dosages, growth hormone therapy is generally believed to be safe..$^{12-14}$

Large observational studies of growth-hormone-treated patients have been used to examine long-term outcomes and safety in "real-world" settings. ${ }^{15-21}$ These include the phase IV prospective observational Genetics and Neuroendocrinology of Short Stature International Study (GeNeSIS), implemented in 1999, which enrolled over 23000 patients from 827 sites in 30 countries. Canada has a long history in helping establish growth hormone safety and effectiveness through clinical trials and surveillance programs, ${ }^{4,22-24}$ beginning in the 1960s and continuing until 2015 with GeNeSIS. Although

Competing interests: See the end of the article.

*A list of the investigators is provided at the end of the article.

This article has been peer reviewed.

Correspondence to: Cheri Deal, Cheri.L.Deal@umontreal.ca

CMAJ Open 2018. DOI:10.9778/cmajo.20180020 
such multinational surveillance studies provide global information, uptake and outcomes of growth hormone treatment across and between countries may be affected by differences in indications and dosages, age chosen for treatment initiation, funding sources for treatment and patient characteristics. Country-specific data on outcomes of growth hormone therapy have been reported to only a limited extent. ${ }^{19,25-28}$ The objective of the current report was to evaluate outcomes of growth hormone treatment in pediatric patients in Canada, comparing findings with those from the United States and the overall global population, using data from GeNeSIS.

\section{Methods}

\section{Patient population}

The multinational phase IV prospective observational study GeNeSIS was designed to examine the safety and effectiveness of growth hormone (Humatrope, Eli Lilly and Company) administered in children with growth disorders.

The observational nature of GeNeSIS meant that all diagnoses and measurements were as reported by and all treatment decisions were at the discretion of the participating investigator. Growth hormone deficiency and idiopathic short stature were defined with the use of current guidelines. ${ }^{14,29}$ The definition of short stature is an auxological one, referring to measured height in a child that is -2 standard deviations (SDs) beneath the population mean. Abnormal growth velocity is defined as the crossing of growth centiles in a child or adolescent and therefore requires serial growth measurements, typically 3-6 months apart. Patients were enrolled at 14 centres in Canada. The present report examined data from the start of the study, in April 1999, until study completion, in September 2015.

\section{Study evaluations}

The 2000 US National Center for Health Statistics standards ${ }^{30}$ were used to calculate height SD score (SDS) for all countries in GeNeSIS except Japan. Prespecified age- and sex-matched reference data ${ }^{31}$ were used for height velocity SDS. Target height was based on the sex-adjusted average of parental heights where available; pubertal stage was recorded according to the Tanner classification. ${ }^{32,33}$ Near-adult height was defined as the patient's having reached 1 of the following criteria: closed epiphyses, height velocity less than $2 \mathrm{~cm} / \mathrm{yr}$, or bone age greater than 14 years for girls or greater than 16 years for boys.

Adverse events were categorized according to the Medical Dictionary for Regulatory Activities (MedDRA, International Council for Harmonisation of Technical Requirements for Pharmaceuticals for Human Use) version 18.1, with the investigators' assessing the potential relation to growth hormone treatment (possibly/probably or not related). Serious adverse events were classified according to Canadian guidelines. ${ }^{34}$ Treatment-emergent adverse events were defined as events that first occurred or worsened in severity after the start of growth hormone treatment and, thus, were evaluated only in those with at least 1 postbaseline visit.

\section{Statistical analysis}

The observational nature of the study meant that various data were missing for some patients. Each analysis used the maximum available data, and patient numbers therefore varied between specific analyses. Changes in auxological parameters during treatment were evaluated for the following patient subgroups: 1) growth hormone naive at entry, with both baseline and 1 -year height SDS data $(n=274), 2)$ growth hormone naive at entry, with yearly height measurements for at least 4 years $(n=165)$ and 3$)$ reached near-adult height during the study and were either growth hormone naive or already treated with growth hormone at entry to GeNeSIS $(n=293)$. Data are presented as mean with $95 \%$ confidence interval (CI) for continuous variables, and as frequency and percentage for categorical variables. Outcomes across different groups could be compared by examination of the overlap of $95 \%$ CI. We conducted statistical analyses using SAS 9.1 (SAS Institute).

\section{Ethics approval}

Data were collected according to the ethical principles of the Declaration of Helsinki, and the protocol was approved by appropriate local ethics review committees. Written informed consent for data collection, processing and publication was provided by a parent/legal guardian according to national laws and regulations.

\section{Results}

\section{Patient characteristics}

Data for 848 growth-hormone-treated Canadian children (430 boys [50.7\%] and 417 girls [49.2\%]; in 1 case [0.1\%], the sex was unknown) were evaluable for effectiveness analyses; data for 2 further patients were included only in safety analyses. At GeNeSIS entry, 528 children $(62.3 \%)$ were already receiving growth hormone, and 320 (37.7\%) were growth hormone naive. Ethnic origin was white for 308/342 patients $(90.1 \%)$ with relevant information; however, ethnicity data were not provided for 508 patients $(59.8 \%)$. The most frequent primary diagnosis was growth hormone deficiency $(526$ [61.9\%]) (Table 1), reported to be due to organic causes in most cases (379/526 [72.1\%]). Of the 379 patients with organic growth hormone deficiency, 184 (48.5\%) had congenital pituitary development abnormalities, and 102 (26.9\%) had an intracranial tumour. After growth hormone deficiency, the next largest diagnostic category was Turner syndrome (156 [18.4\%]). The proportions of children with idiopathic growth hormone deficiency and idiopathic short stature were higher in the US than in Canada, whereas the proportion with Turner syndrome appeared lower in the US (Table 1).

The overall mean age at the start of growth hormone treatment was 8.5 years (range $0.01-18.2 \mathrm{yr}$ ). For diagnostic groups most frequently reported (Supplementary Table A1, Appendix 1, available at www.cmajopen.ca/content/6/3/E372/ suppl/DC1), the mean age at the start of growth hormone treatment was highest for patients with idiopathic short stature. Patients with organic growth hormone deficiency had a 


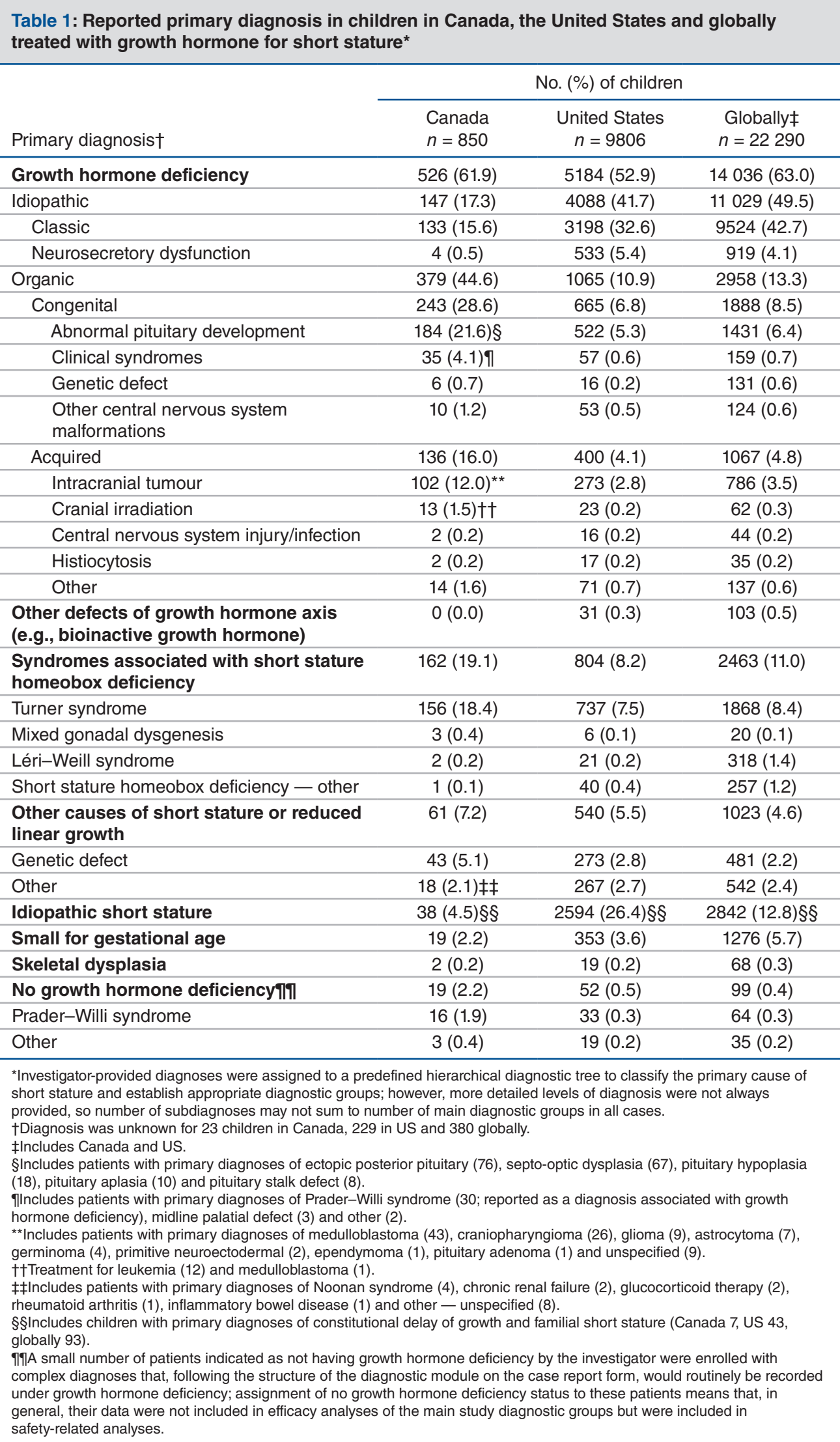


lower mean age at the start of treatment than did patients with idiopathic growth hormone deficiency. Age at the start of treatment was 10 years or more for $47.5 \%(n=180)$ of patients with organic growth hormone deficiency, 64.6\% $(n=$ 95) of those with idiopathic growth hormone deficiency, $57.1 \%(n=89)$ of those with Turner syndrome and $78.9 \%$ $(n=30)$ of those with idiopathic short stature. At baseline, most patients (278/324 girls [85.8\%] and 234/293 boys [79.9\%]) were prepubertal, with similar proportions across diagnostic groups except for idiopathic short stature $(40.0 \%$ [ $n=2 / 5]$ and $48.0 \%$ [ $n=12 / 25]$, respectively).

The mean peak growth hormone level in growth hormone stimulation tests was less than $5 \mu \mathrm{g} / \mathrm{L}$ for both patients with organic growth hormone deficiency and those with idiopathic growth hormone deficiency, versus $24.1 \mu \mathrm{g} / \mathrm{L}$ for those with idiopathic short stature. Stimulated peak growth hormone levels in Canadian children with growth hormone deficiency were lower than those in the global cohort (Supplementary Table A1, Appendix 1). The mean dosage at the start of growth hormone treatment was highest for patients with Turner syndrome (0.29 [95\% CI 0.28 to 0.29$] \mathrm{mg} / \mathrm{kg}$ per wk) and lowest for patients with organic growth hormone deficiency $(0.18$ [95\% CI 0.18 to 0.19$] \mathrm{mg} / \mathrm{kg}$ per wk). Canadian mean growth hormone dosages were lower than those in the US (data not shown) or global cohorts. The reported mean duration of growth hormone treatment was 6.6 (95\% CI 6.3 to 6.9$)$ years

\begin{tabular}{|c|c|c|c|c|c|}
\hline \multirow[b]{2}{*}{ Characteristic } & \multicolumn{5}{|c|}{ Diagnostic category; mean $(95 \% \mathrm{Cl}) \dagger$} \\
\hline & $\begin{array}{l}\text { Organic growth } \\
\text { hormone deficiency }\end{array}$ & $\begin{array}{l}\text { Idiopathic growth } \\
\text { hormone } \\
\text { deficiency }\end{array}$ & $\begin{array}{l}\text { Turner } \\
\text { syndrome }\end{array}$ & $\begin{array}{l}\text { Idiopathic short } \\
\text { stature }\end{array}$ & $\begin{array}{c}\text { Small for } \\
\text { gestational age }\end{array}$ \\
\hline Canada & $n=89$ & $n=57$ & $n=44$ & $n=25$ & $n=5$ \\
\hline \multicolumn{6}{|l|}{ Baseline } \\
\hline Male sex, no. (\%) & $54(61)$ & $38(67)$ & - & $21(84)$ & $4(80)$ \\
\hline Age, yr & $\begin{array}{c}8.9 \\
(7.8 \text { to } 10.0)\end{array}$ & $\begin{array}{c}11.3 \\
(10.2 \text { to } 12.4)\end{array}$ & $\begin{array}{c}9.6 \\
\text { (8.5 to } 10.6)\end{array}$ & $\begin{array}{c}12.9 \\
(11.8 \text { to } 14.0)\end{array}$ & $\begin{array}{c}6.3 \\
\text { (3.7 to } 9.0)\end{array}$ \\
\hline Height SDS & $\begin{array}{c}-1.87 \\
(-2.13 \text { to }-1.60)\end{array}$ & $\begin{array}{c}-2.58 \\
(-2.91 \text { to }-2.25)\end{array}$ & $\begin{array}{c}-2.76 \\
(-2.97 \text { to }-2.55)\end{array}$ & $\begin{array}{c}-2.57 \\
(-2.96 \text { to }-2.18)\end{array}$ & $\begin{array}{c}-4.02 \\
(-5.40 \text { to }-2.65)\end{array}$ \\
\hline Height velocity, cm/yr & $\begin{array}{c}5.17 \\
\text { (4.12 to } 6.22)\end{array}$ & $\begin{array}{c}4.22 \\
\text { (3.39 to } 5.04)\end{array}$ & $\begin{array}{c}4.96 \\
\text { (4.24 to } 5.67)\end{array}$ & $\begin{array}{c}4.58 \\
(3.78 \text { to } 5.37)\end{array}$ & $\begin{array}{c}6.32 \\
\text { (3.15 to } 9.49)\end{array}$ \\
\hline Height velocity SDS & $\begin{array}{c}-1.65 \\
(-2.05 \text { to }-1.24)\end{array}$ & $\begin{array}{c}-1.55 \\
(-2.04 \text { to }-1.05)\end{array}$ & $\begin{array}{c}-1.01 \\
(-1.54 \text { to }-0.47)\end{array}$ & $\begin{array}{c}-0.61 \\
(-1.58 \text { to } 0.35)\end{array}$ & $\begin{array}{c}0.31 \\
(-4.70 \text { to } 5.32)\end{array}$ \\
\hline Target height SDS & $\begin{array}{c}0.25 \\
(0.03 \text { to } 0.47)\end{array}$ & $\begin{array}{c}-0.37(-0.64 \text { to } \\
-0.10)\end{array}$ & $\begin{array}{c}0.18 \\
(-0.04 \text { to } 0.40)\end{array}$ & $\begin{array}{c}-0.44 \\
(-0.72 \text { to }-0.15)\end{array}$ & $\begin{array}{c}-0.62(-1.26 \text { to } \\
0.03)\end{array}$ \\
\hline Target height SDS deficitł & $\begin{array}{c}-2.19 \\
(-2.54 \text { to }-1.84)\end{array}$ & $\begin{array}{c}-2.22 \\
(-2.62 \text { to }-1.83)\end{array}$ & $\begin{array}{c}-2.92 \\
(-3.18 \text { to }-2.66)\end{array}$ & $\begin{array}{c}-2.13 \\
(-2.55 \text { to }-1.72)\end{array}$ & $\begin{array}{c}-3.41 \\
(-5.16 \text { to }-1.65)\end{array}$ \\
\hline $\begin{array}{l}\text { Stimulated peak growth } \\
\text { hormone level, } \mu \mathrm{g} / \mathrm{L}\end{array}$ & $\begin{array}{c}4.3 \\
\text { (2.4 to } 6.1)\end{array}$ & $\begin{array}{c}4.4 \\
\text { (3.6 to } 5.3)\end{array}$ & NA & $\begin{array}{c}25.0 \\
(17.2 \text { to } 32.8)\end{array}$ & NA \\
\hline $\begin{array}{l}\text { Growth hormone dosage, } \\
\mathrm{mg} / \mathrm{kg} \text { per wk }\end{array}$ & $\begin{array}{c}0.18 \\
(0.17 \text { to } 0.19)\end{array}$ & $\begin{array}{c}0.18 \\
(0.17 \text { to } 0.19)\end{array}$ & $\begin{array}{c}0.29 \\
(0.28 \text { to } 0.30)\end{array}$ & $\begin{array}{c}0.22 \\
(0.19 \text { to } 0.25)\end{array}$ & $\begin{array}{c}0.22 \\
(0.15 \text { to } 0.29)\end{array}$ \\
\hline \multicolumn{6}{|l|}{ Year 1} \\
\hline Height SDS & $\begin{array}{c}-1.30 \\
(-1.54 \text { to }-1.05)\end{array}$ & $\begin{array}{c}-1.97 \\
(-2.29 \text { to }-1.65)\end{array}$ & $\begin{array}{c}-2.28 \\
(-2.54 \text { to }-2.03)\end{array}$ & $\begin{array}{c}-2.24 \\
(-2.64 \text { to }-1.83)\end{array}$ & $\begin{array}{c}-3.45 \\
(-4.75 \text { to }-2.15)\end{array}$ \\
\hline Height velocity, cm/yr & $\begin{array}{c}9.30 \\
\text { (8.28 to } 10.33)\end{array}$ & $\begin{array}{c}8.79 \\
\text { (8.14 to } 9.44)\end{array}$ & $\begin{array}{c}7.84 \\
\text { (7.28 to } 8.40)\end{array}$ & $\begin{array}{c}7.31 \\
(6.33 \text { to } 8.28)\end{array}$ & $\begin{array}{c}7.24 \\
\text { (5.59 to } 8.90)\end{array}$ \\
\hline Height velocity SDS & $\begin{array}{c}1.72 \\
(1.31 \text { to } 2.13)\end{array}$ & $\begin{array}{c}2.20 \\
(1.58 \text { to } 2.81)\end{array}$ & $\begin{array}{c}2.54 \\
\text { (1.54 to } 3.53)\end{array}$ & $\begin{array}{c}1.47 \\
(0.76 \text { to } 2.17)\end{array}$ & $\begin{array}{c}1.49 \\
(-0.12 \text { to } 3.10)\end{array}$ \\
\hline Height SDS gain & $\begin{array}{c}0.59 \\
(0.43 \text { to } 0.76)\end{array}$ & $\begin{array}{c}0.60 \\
(0.46 \text { to } 0.73)\end{array}$ & $\begin{array}{c}0.50 \\
(0.38 \text { to } 0.61)\end{array}$ & $\begin{array}{c}0.33 \\
(0.21 \text { to } 0.45)\end{array}$ & $\begin{array}{c}0.57 \\
(0.14 \text { to } 1.00)\end{array}$ \\
\hline Target height SDS deficit $\ddagger$ & $\begin{array}{c}-1.60 \\
(-1.93 \text { to }-1.27)\end{array}$ & $\begin{array}{c}-1.61 \\
(-1.99 \text { to }-1.24)\end{array}$ & $\begin{array}{c}-2.44 \\
(-2.72 \text { to }-2.16) \\
\end{array}$ & $\begin{array}{c}-1.80 \\
(-2.23 \text { to }-1.36)\end{array}$ & $\begin{array}{c}-2.83 \\
(-4.46 \text { to }-1.20)\end{array}$ \\
\hline $\begin{array}{l}\text { Growth hormone dosage, } \\
\mathrm{mg} / \mathrm{kg} \text { per wk }\end{array}$ & $\begin{array}{c}0.19 \\
(0.18 \text { to } 0.20)\end{array}$ & $\begin{array}{c}0.19 \\
(0.18 \text { to } 0.20)\end{array}$ & $\begin{array}{c}0.30 \\
(0.29 \text { to } 0.31)\end{array}$ & $\begin{array}{c}0.24 \\
(0.21 \text { to } 0.27)\end{array}$ & $\begin{array}{c}0.27 \\
(0.21 \text { to } 0.33)\end{array}$ \\
\hline
\end{tabular}


overall and was longest for patients with organic growth hormone deficiency $(8.0 \mathrm{yr}, 95 \%$ CI 7.5 to $8.4 \mathrm{yr})$ and shortest for those with idiopathic short stature $(2.7 \mathrm{yr}, 95 \%$ CI 2.2 to $3.2 \mathrm{yr}$; not all data shown). The duration of growth hormone treatment was more than 4 years for 556 patients $(65.4 \%)$.

\section{Height data during growth hormone therapy}

Auxological data at baseline and at 1 year for patients naive to growth hormone treatment at study entry are summa- rized in Table 2 for Canada and the global database. For Canadian patients overall, the mean height velocity SDS increased from -1.19 (95\% CI -1.43 to -0.94$)$ at baseline to 1.97 (95\% CI 1.69 to 2.26 ) at 1 year. All diagnostic groups had a mean gain in height SDS at 1 year, with the least gain in those with idiopathic short stature $(0.33$ [95\% CI 0.21 to 0.45$]$ ) and the greatest gain in patients with idiopathic growth hormone deficiency (0.60 [95\% CI 0.46 to 0.73$])$.

\section{Table 2 (part 2 of 2): Patient characteristics and auxological data at baseline and after 1 year of growth hormone treatment for patients naive to growth hormone treatment at study entry and with baseline and 1-year height measurements available, by primary diagnostic category*}

\begin{tabular}{|c|c|c|c|c|c|}
\hline \multirow[b]{2}{*}{ Characteristic } & \multicolumn{5}{|c|}{ Diagnostic category; mean $(95 \% \mathrm{Cl}) \dagger$} \\
\hline & $\begin{array}{l}\text { Organic growth } \\
\text { hormone deficiency }\end{array}$ & $\begin{array}{l}\text { Idiopathic growth } \\
\text { hormone } \\
\text { deficiency }\end{array}$ & $\begin{array}{l}\text { Turner } \\
\text { syndrome }\end{array}$ & $\begin{array}{l}\text { Idiopathic short } \\
\text { stature }\end{array}$ & $\begin{array}{c}\text { Small for } \\
\text { gestational age }\end{array}$ \\
\hline $\begin{array}{l}\text { All countries combined } \\
\text { (including Canada) }\end{array}$ & $n=1210$ & $n=5974$ & $n=886$ & $n=1353$ & $n=756$ \\
\hline \multicolumn{6}{|l|}{ Baseline } \\
\hline Male sex, no. (\%) & 766 (63.3) & $3988(66.8)$ & - & $967(71.5)$ & $405(53.6)$ \\
\hline Age, yr & $\begin{array}{c}8.8 \\
\text { (8.5 to } 9.1)\end{array}$ & $\begin{array}{c}10.3 \\
(10.2 \text { to } 10.4)\end{array}$ & $\begin{array}{c}9.2 \\
\text { (9.0 to } 9.4)\end{array}$ & $\begin{array}{c}11.5 \\
(11.3 \text { to } 11.6)\end{array}$ & $\begin{array}{c}8.6 \\
\text { (8.3 to } 8.8)\end{array}$ \\
\hline Height SDS & $\begin{array}{c}-2.42 \\
(-2.50 \text { to }-2.34)\end{array}$ & $\begin{array}{c}-2.39 \\
(-2.41 \text { to }-2.37)\end{array}$ & $\begin{array}{c}-2.56 \\
(-2.62 \text { to }-2.50)\end{array}$ & $\begin{array}{c}-2.36 \\
(-2.40 \text { to }-2.32)\end{array}$ & $\begin{array}{c}-2.62 \\
(-2.68 \text { to }-2.56)\end{array}$ \\
\hline Height velocity, $\mathrm{cm} / \mathrm{yr}$ & $\begin{array}{c}4.54 \\
(4.32 \text { to } 4.75)\end{array}$ & $\begin{array}{c}4.70 \\
(4.64 \text { to } 4.77)\end{array}$ & $\begin{array}{c}4.86 \\
(4.66 \text { to } 5.06)\end{array}$ & $\begin{array}{c}4.81 \\
(4.65 \text { to } 4.96)\end{array}$ & $\begin{array}{c}5.22 \\
(5.02 \text { to } 5.41)\end{array}$ \\
\hline Height velocity SDS & $\begin{array}{c}-1.56 \\
(-1.70 \text { to }-1.42)\end{array}$ & $\begin{array}{c}-0.99 \\
(-1.04 \text { to }-0.93)\end{array}$ & $\begin{array}{c}-1.11 \\
(-1.26 \text { to }-0.96)\end{array}$ & $\begin{array}{c}-0.72 \\
(-0.84 \text { to }-0.60)\end{array}$ & $\begin{array}{c}-0.84 \\
(-0.99 \text { to }-0.69)\end{array}$ \\
\hline Target height SDS & $\begin{array}{c}-0.06 \\
(-0.11 \text { to } 0.00)\end{array}$ & $\begin{array}{c}-0.55 \\
(-0.57 \text { to }-0.53)\end{array}$ & $\begin{array}{c}0.07 \\
(0.01 \text { to } 0.13)\end{array}$ & $\begin{array}{c}-0.54 \\
(-0.59 \text { to }-0.50)\end{array}$ & $\begin{array}{c}-0.64 \\
(-0.70 \text { to }-0.58)\end{array}$ \\
\hline Target height SDS deficitł & $\begin{array}{c}-2.42 \\
(-2.50 \text { to }-2.33)\end{array}$ & $\begin{array}{c}-1.84 \\
(-1.86 \text { to }-1.81)\end{array}$ & $\begin{array}{c}-2.62 \\
(-2.69 \text { to }-2.55)\end{array}$ & $\begin{array}{c}-1.82 \\
(-1.87 \text { to }-1.76)\end{array}$ & $\begin{array}{c}-1.98 \\
(-2.07 \text { to }-1.90)\end{array}$ \\
\hline $\begin{array}{l}\text { Stimulated peak growth } \\
\text { hormone level, } \mu \mathrm{g} / \mathrm{L}\end{array}$ & $\begin{array}{c}4.5 \\
(4.1 \text { to } 4.8)\end{array}$ & $\begin{array}{c}8.2 \\
(8.0 \text { to } 8.4)\end{array}$ & $\mathrm{N} / \mathrm{A}$ & $\begin{array}{c}16.9 \\
(16.3 \text { to } 17.4)\end{array}$ & $\begin{array}{c}14.1 \\
(13.1 \text { to } 15.1)\end{array}$ \\
\hline $\begin{array}{l}\text { Growth hormone dosage, } \\
\mathrm{mg} / \mathrm{kg} \text { per wk }\end{array}$ & $\begin{array}{c}0.22 \\
(0.21 \text { to } 0.22)\end{array}$ & $\begin{array}{c}0.23 \\
(0.23 \text { to } 0.24)\end{array}$ & $\begin{array}{c}0.31 \\
(0.31 \text { to } 0.32)\end{array}$ & $\begin{array}{c}0.32 \\
(0.32 \text { to } 0.33)\end{array}$ & $\begin{array}{c}0.27 \\
(0.27 \text { to } 0.28)\end{array}$ \\
\hline \multicolumn{6}{|l|}{ Year 1} \\
\hline Height SDS & $\begin{array}{c}-1.65 \\
(-1.72 \text { to }-1.58)\end{array}$ & $\begin{array}{c}-1.85 \\
(-1.87 \text { to }-1.83)\end{array}$ & $\begin{array}{c}-2.10 \\
(-2.16 \text { to }-2.04)\end{array}$ & $\begin{array}{c}-1.87 \\
(-1.91 \text { to }-1.82)\end{array}$ & $\begin{array}{c}-2.05 \\
(-2.11 \text { to }-2.00)\end{array}$ \\
\hline Height velocity, cm/yr & $\begin{array}{c}9.76 \\
\text { (9.54 to } 9.98)\end{array}$ & $\begin{array}{c}8.79 \\
(8.73 \text { to } 8.85)\end{array}$ & $\begin{array}{c}7.83 \\
\text { (7.70 to } 7.97)\end{array}$ & $\begin{array}{c}8.63 \\
(8.51 \text { to } 8.76)\end{array}$ & $\begin{array}{c}8.52 \\
\text { (8.37 to } 8.68)\end{array}$ \\
\hline Height velocity SDS & $\begin{array}{c}3.21 \\
(3.02 \text { to } 3.40)\end{array}$ & $\begin{array}{c}2.48 \\
(2.42 \text { to } 2.54)\end{array}$ & $\begin{array}{c}2.26 \\
\text { (2.07 to } 2.45)\end{array}$ & $\begin{array}{c}2.38 \\
(2.26 \text { to } 2.50)\end{array}$ & $\begin{array}{c}2.34 \\
\text { (2.19 to } 2.49)\end{array}$ \\
\hline Height SDS gain & $\begin{array}{c}0.78 \\
(0.74 \text { to } 0.82)\end{array}$ & $\begin{array}{c}0.56 \\
(0.55 \text { to } 0.57)\end{array}$ & $\begin{array}{c}0.48 \\
(0.46 \text { to } 0.51)\end{array}$ & $\begin{array}{c}0.52 \\
(0.50 \text { to } 0.54)\end{array}$ & $\begin{array}{c}0.58 \\
(0.55 \text { to } 0.61)\end{array}$ \\
\hline Target height SDS deficitł & $\begin{array}{c}-1.63 \\
(-1.70 \text { to }-1.55)\end{array}$ & $\begin{array}{c}-1.29 \\
(-1.32 \text { to }-1.27)\end{array}$ & $\begin{array}{c}-2.16 \\
(-2.23 \text { to }-2.09)\end{array}$ & $\begin{array}{c}-1.31 \\
(-1.37 \text { to }-1.26)\end{array}$ & $\begin{array}{c}-1.41 \\
(-1.49 \text { to }-1.33)\end{array}$ \\
\hline $\begin{array}{l}\text { Growth hormone dosage, } \\
\mathrm{mg} / \mathrm{kg} \text { per wk }\end{array}$ & $\begin{array}{c}0.23 \\
(0.22 \text { to } 0.23)\end{array}$ & $\begin{array}{c}0.25 \\
(0.25 \text { to } 0.25)\end{array}$ & $\begin{array}{c}0.32 \\
(0.32 \text { to } 0.33)\end{array}$ & $\begin{array}{c}0.35 \\
(0.35 \text { to } 0.36)\end{array}$ & $\begin{array}{c}0.29 \\
(0.29 \text { to } 0.30)\end{array}$ \\
\hline $\begin{array}{l}\text { Note: } \mathrm{Cl}=\text { confidence interval, } \mathrm{NA}= \\
{ }^{*} \text { Patient numbers are for those with } \\
\text { †Except where noted otherwise. } \\
\text { fHeight SDS minus target height SD }\end{array}$ & ilable for less than 60 & tients, SDS = stanc & $\begin{array}{l}\text { eviation score. } \\
\text { her information. }\end{array}$ & & \\
\hline
\end{tabular}


Mean height SDS and height velocity SDS over the first 4 years of growth hormone treatment are shown in Figure 1. For each diagnostic group, mean height velocity SDS increased in the first year and declined over subsequent years.

Auxological parameters for all patients who reached nearadult height are shown in Table 3, and mean gain in height SDS is shown in Figure 2. Near-adult height SDS was greater than -2.0 for most Canadian patients with organic growth hormone deficiency and idiopathic growth hormone deficiency but for only about half of those with Turner syndrome or idiopathic short stature. Mean age at baseline was lower and mean therapy duration to near-adult height was longer for patients with organic growth hormone deficiency than for those with idiopathic growth hormone deficiency; however, this did not result in a greater mean change from baseline for height SDS (Figure 2).

\section{Safety outcomes}

Of the 850 Canadian children included in the safety analysis (Table 4), 11 died during the study period; patient characteristics and cause of death are shown in Supplementary Table A2, Appendix 1. Seven patients with organic growth hormone deficiency died. Death was considered possibly related to growth hormone treatment by the investigator for 3 of these patients, for whom the primary diagnosis was medulloblastoma $(n=2)$ or anaplastic astrocytoma $(n=1)$; the cause of death was tumour recurrence in each case.

Serious adverse events were reported for 97 patients, with events in 19 patients (2.2\%; see Table 4 footnote) considered by the investigator to be related to growth hormone treatment. The treatment-related serious adverse events were single events in individual patients
A

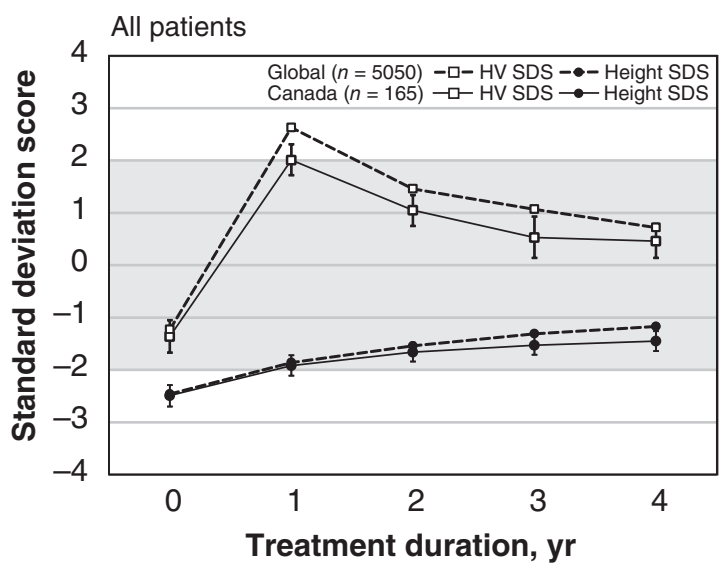

C

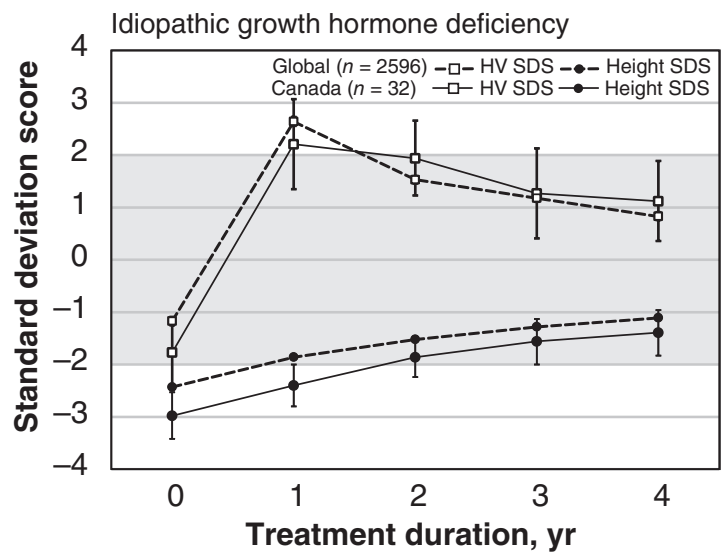

B

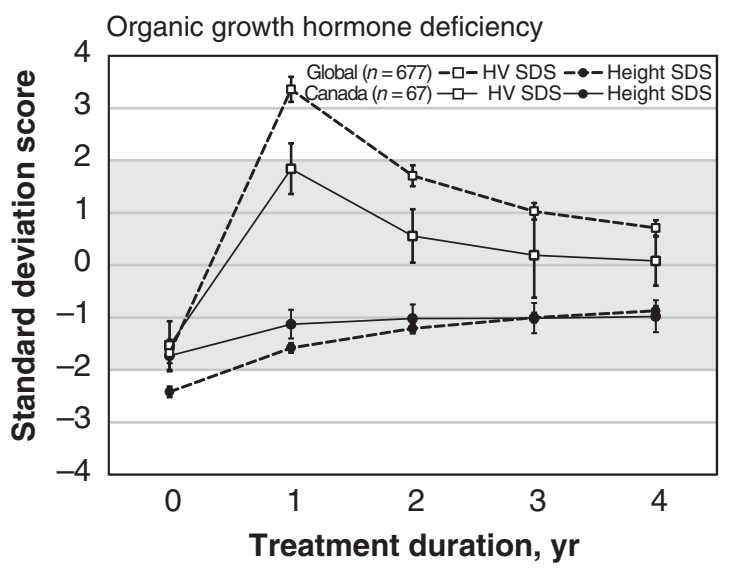

D

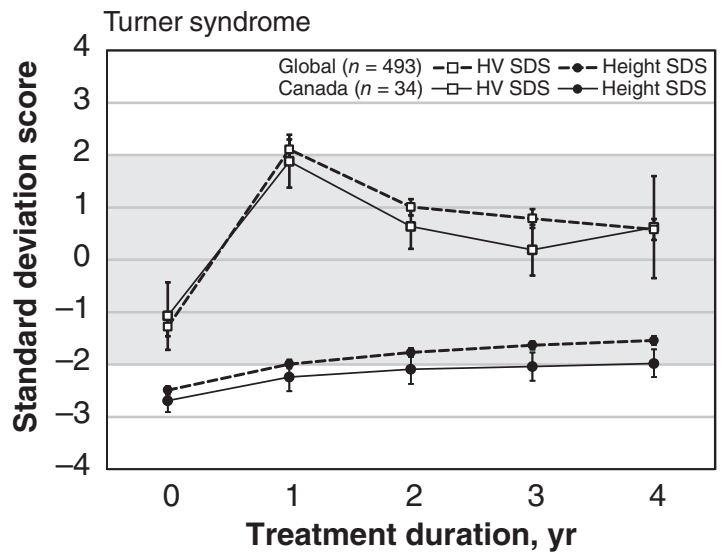

Figure 1: Mean height velocity standard deviation score (HV SDS) and height SDS over the first 4 years of growth hormone treatment for patients in Canada and the global population with data for each year who were naive to growth hormone treatment at study entry, for all patients ([A]) and for evaluable diagnostic groups ([B], $[\mathrm{C}]$ and $[\mathrm{D}])$. Standard deviation score corresponds to the following height percentiles on a standard height-for-age growth curve: -3 SDS $=0.2 \%,-2$ SDS $=2.3 \%,-1$ SDS $=16.0 \%, 0$ SDS $=50.0 \%, 1$ SDS $=86.0 \%, 2$ SDS $=97.7 \%, 3$ SDS $=99.8 \%$. Data for patients with idiopathic short stature are not shown because of the small number of patients $(n=9)$ in this diagnostic group in Canada with relevant data. Grey shading delineates "normal" values within \pm 2 SDs. Error bars $=95 \%$ confidence intervals. 


\begin{tabular}{|c|c|c|c|c|c|}
\hline \multirow[b]{2}{*}{ Characteristic } & \multicolumn{5}{|c|}{ Diagnostic category; mean $(95 \% \mathrm{Cl})^{\star}$} \\
\hline & All patients & $\begin{array}{l}\text { Organic growth } \\
\text { hormone } \\
\text { deficiency }\end{array}$ & $\begin{array}{l}\text { Idiopathic growth } \\
\text { hormone } \\
\text { deficiency }\end{array}$ & $\begin{array}{l}\text { Turner } \\
\text { syndrome }\end{array}$ & $\begin{array}{l}\text { Idiopathic short } \\
\text { stature }\end{array}$ \\
\hline Canada & $n=293$ & $n=131$ & $n=50$ & $n=79$ & $n=10$ \\
\hline \multicolumn{6}{|l|}{ Baseline } \\
\hline Male sex, no. (\%) & $147(50.2)$ & $89(67.9)$ & $33(66.0)$ & - & $9(90.0)$ \\
\hline Age, yr & $\begin{array}{c}10.2 \\
(9.8 \text { to } 10.6)\end{array}$ & $\begin{array}{c}9.2 \\
(8.5 \text { to } 9.9)\end{array}$ & $\begin{array}{c}11.4 \\
(10.4 \text { to } 12.5)\end{array}$ & $\begin{array}{c}10.3 \\
(9.8 \text { to } 10.9)\end{array}$ & $\begin{array}{c}12.8 \\
(11.3 \text { to } 14.4)\end{array}$ \\
\hline Height SDS & $\begin{array}{c}-2.62 \\
(-2.78 \text { to }-2.46)\end{array}$ & $\begin{array}{c}-2.29 \\
(-2.57 \text { to }-2.00)\end{array}$ & $\begin{array}{c}-2.70 \\
(-3.06 \text { to }-2.33)\end{array}$ & $\begin{array}{c}-2.99 \\
(-3.15 \text { to }-2.83)\end{array}$ & $\begin{array}{c}-2.52 \\
(-3.25 \text { to }-1.79)\end{array}$ \\
\hline Target height SDS deficit† & $\begin{array}{c}-2.51 \\
(-2.69 \text { to }-2.32)\end{array}$ & $\begin{array}{c}-2.32 \\
(-2.62 \text { to }-2.02)\end{array}$ & $\begin{array}{c}-2.14 \\
(-2.56 \text { to }-1.71)\end{array}$ & $\begin{array}{c}-2.91 \\
(-3.11 \text { to }-2.71)\end{array}$ & $\begin{array}{c}-1.81 \\
(-2.61 \text { to }-1.01)\end{array}$ \\
\hline Height velocity SDS & $\begin{array}{c}-1.49 \\
(-1.71 \text { to }-1.27)\end{array}$ & $\begin{array}{c}-1.89 \\
(-2.23 \text { to }-1.54)\end{array}$ & $\begin{array}{c}-1.29 \\
(-1.75 \text { to }-0.83)\end{array}$ & $\begin{array}{c}-1.16 \\
(-1.44 \text { to }-0.89)\end{array}$ & $\begin{array}{c}-0.25 \\
(-1.32 \text { to } 0.83)\end{array}$ \\
\hline $\begin{array}{l}\text { Growth hormone dosage, } \\
\mathrm{mg} / \mathrm{kg} \text { per wk }\end{array}$ & $\begin{array}{c}0.22 \\
(0.21 \text { to } 0.23)\end{array}$ & $\begin{array}{c}0.18 \\
(0.17 \text { to } 0.18)\end{array}$ & $\begin{array}{c}0.20 \\
(0.17 \text { to } 0.23)\end{array}$ & $\begin{array}{c}0.29 \\
(0.28 \text { to } 0.29)\end{array}$ & $\begin{array}{c}0.24 \\
(0.18 \text { to } 0.30)\end{array}$ \\
\hline $\begin{array}{l}\text { Stimulated peak growth } \\
\text { hormone level, } \mu \mathrm{g} / \mathrm{L}\end{array}$ & $\begin{array}{c}4.73 \\
\text { (3.99 to } 5.47)\end{array}$ & $\begin{array}{c}2.90 \\
(2.48 \text { to } 3.32)\end{array}$ & $\begin{array}{c}4.15 \\
(3.36 \text { to } 4.94)\end{array}$ & NA & $\begin{array}{c}19.41 \\
(14.65 \text { to } 24.18)\end{array}$ \\
\hline \multicolumn{6}{|l|}{ Near-adult height } \\
\hline Age, yr & $\begin{array}{c}17.8 \\
(17.6 \text { to } 17.9)\end{array}$ & $\begin{array}{c}18.1 \\
(17.8 \text { to } 18.3)\end{array}$ & $\begin{array}{c}17.6 \\
\text { (17.1 to } 18.1)\end{array}$ & $\begin{array}{c}17.6 \\
(17.3 \text { to } 17.9)\end{array}$ & $\begin{array}{c}17.2 \\
(15.6 \text { to } 18.9)\end{array}$ \\
\hline Height SDS & $\begin{array}{c}-1.42 \\
(-1.56 \text { to }-1.27)\end{array}$ & $\begin{array}{c}-0.95 \\
(-1.15 \text { to }-0.75)\end{array}$ & $\begin{array}{c}-1.07 \\
(-1.38 \text { to }-0.76)\end{array}$ & $\begin{array}{c}-2.04 \\
(-2.24 \text { to }-1.83)\end{array}$ & $\begin{array}{c}-2.02 \\
(-2.89 \text { to }-1.14)\end{array}$ \\
\hline $\begin{array}{l}\text { Near-adult height SDS less } \\
\text { baseline height SDS }\end{array}$ & $\begin{array}{c}1.17 \\
(1.01 \text { to } 1.33)\end{array}$ & $\begin{array}{c}1.26 \\
(0.98 \text { to } 1.54)\end{array}$ & $\begin{array}{c}1.63 \\
(1.27 \text { to } 1.99)\end{array}$ & $\begin{array}{c}0.96 \\
(0.78 \text { to } 1.13)\end{array}$ & $\begin{array}{c}0.50 \\
(-0.35 \text { to } 1.35)\end{array}$ \\
\hline Target height SDS deficit† & $\begin{array}{c}-1.28 \\
(-1.44 \text { to }-1.13)\end{array}$ & $\begin{array}{c}-0.93 \\
(-1.15 \text { to }-0.71)\end{array}$ & $\begin{array}{c}-0.52 \\
(-0.80 \text { to }-0.24)\end{array}$ & $\begin{array}{c}-1.94 \\
(-2.16 \text { to }-1.72)\end{array}$ & $\begin{array}{c}-1.31 \\
(-2.29 \text { to }-0.32)\end{array}$ \\
\hline $\begin{array}{l}\text { Growth hormone therapy } \\
\text { duration, yr }\end{array}$ & $\begin{array}{c}6.46 \\
(6.01 \text { to } 6.90)\end{array}$ & $\begin{array}{c}7.68 \\
(6.93 \text { to } 8.44)\end{array}$ & $\begin{array}{c}5.45 \\
(4.48 \text { to } 6.42)\end{array}$ & $\begin{array}{c}5.71 \\
(5.18 \text { to } 6.25)\end{array}$ & $\begin{array}{c}3.19 \\
(1.97 \text { to } 4.42)\end{array}$ \\
\hline $\begin{array}{l}\text { Last growth hormone } \\
\text { dosage, } \mathrm{mg} / \mathrm{kg} \text { per wk }\end{array}$ & $\begin{array}{c}0.22 \\
(0.21 \text { to } 0.23)\end{array}$ & $\begin{array}{c}0.17 \\
(0.16 \text { to } 0.18)\end{array}$ & $\begin{array}{c}0.20 \\
(0.19 \text { to } 0.22)\end{array}$ & $\begin{array}{c}0.29 \\
(0.28 \text { to } 0.30)\end{array}$ & $\begin{array}{c}0.24 \\
(0.18 \text { to } 0.30)\end{array}$ \\
\hline $\begin{array}{l}\text { Near-adult height SDS } \\
>-2.0, \text { no. }(\%)\end{array}$ & 66 & 79 & 80 & 46 & 50 \\
\hline
\end{tabular}

except for the aforementioned 2 medulloblastoma recurrences and adenoidal hypertrophy in 2 patients.

Of the 833 patients with at least 1 postbaseline visit, 587 $(70.5 \%)$ had at least 1 treatment-emergent adverse event reported (Table 4). Treatment-emergent adverse events were reported more frequently among patients with organic growth hormone deficiency than among those with idiopathic growth hormone deficiency or other diagnoses. The most frequently reported treatment-emergent adverse events for Canadian patients overall were headache and secondary hypothyroidism, consistent with the known growth hormone safety profile and inherent risk of hypothyroidism owing to the underlying diagnosis. Treatment-emergent adverse events classified by the investigator as possibly related to growth hormone treatment occurred in 87 patients (10.2\%).

\section{Interpretation}

The results of GeNeSIS indicated a positive treatment effect on height gain, both during the first 1-4 years of growth hormone therapy and at near-adult height, and a reassuring safety profile both within Canada and globally. Of the 30 countries involved in GeNeSIS, Canada was the sixth-largest contributor of patients, with 850 growth-hormone-treated patients $(3.9 \%)$ out of roughly 22000 globally. Currently approved pediatric indications in Canada are growth hormone deficiency (approved in 1987), Turner syndrome (1997), small for gestational age (2006), idiopathic short stature (2006) and SHOX deficiency (2008); chronic renal insufficiency is an approved indication for some growth hormone formulations (1996) but not for the growth hormone primarily used in GeNeSIS. 


\begin{tabular}{|c|c|c|c|c|c|}
\hline \multirow[b]{2}{*}{ Characteristic } & \multicolumn{5}{|c|}{ Diagnostic category; mean $(95 \% \mathrm{Cl})^{*}$} \\
\hline & All patients & $\begin{array}{l}\text { Organic growth } \\
\text { hormone } \\
\text { deficiency }\end{array}$ & $\begin{array}{l}\text { Idiopathic growth } \\
\text { hormone } \\
\text { deficiency }\end{array}$ & $\begin{array}{l}\text { Turner } \\
\text { syndrome }\end{array}$ & $\begin{array}{l}\text { Idiopathic short } \\
\text { stature }\end{array}$ \\
\hline $\begin{array}{l}\text { All countries combined } \\
\text { (including Canada) }\end{array}$ & $n=5076$ & $n=754$ & $n=2322$ & $n=695$ & $n=552$ \\
\hline \multicolumn{6}{|l|}{ Baseline } \\
\hline Male sex, no. (\%) & $2576(50.7)$ & $448(59.4)$ & $1412(60.8)$ & - & $360(65.2)$ \\
\hline Age, yr & $\begin{array}{c}10.9 \\
(10.8 \text { to } 11.0)\end{array}$ & $\begin{array}{c}9.8 \\
(9.5 \text { to } 10.1)\end{array}$ & $\begin{array}{c}11.2 \\
(11.1 \text { to } 11.3)\end{array}$ & $\begin{array}{c}10.0 \\
(9.8 \text { to } 10.3)\end{array}$ & $\begin{array}{c}12.3 \\
(12.0 \text { to } 12.5)\end{array}$ \\
\hline Height SDS & $\begin{array}{c}-2.42 \\
(-2.45 \text { to }-2.40)\end{array}$ & $\begin{array}{c}-2.27 \\
(-2.38 \text { to }-2.17)\end{array}$ & $\begin{array}{c}-2.38 \\
(-2.41 \text { to }-2.34)\end{array}$ & $\begin{array}{c}-2.65 \\
(-2.71 \text { to }-2.58)\end{array}$ & $\begin{array}{c}-2.37 \\
(-2.43 \text { to }-2.30)\end{array}$ \\
\hline Target height SDS deficit† & $\begin{array}{c}-2.02 \\
(-2.06 \text { to }-1.99)\end{array}$ & $\begin{array}{c}-2.29 \\
(-2.40 \text { to }-2.17)\end{array}$ & $\begin{array}{c}-1.80 \\
(-1.85 \text { to }-1.76)\end{array}$ & $\begin{array}{c}-2.69 \\
(-2.77 \text { to }-2.61)\end{array}$ & $\begin{array}{c}-1.74 \\
(-1.83 \text { to }-1.65)\end{array}$ \\
\hline Height velocity SDS & $\begin{array}{c}-1.01 \\
(-1.07 \text { to }-0.95)\end{array}$ & $\begin{array}{c}-1.51 \\
(-1.69 \text { to }-1.33)\end{array}$ & $\begin{array}{c}-0.98 \\
(-1.06 \text { to }-0.89)\end{array}$ & $\begin{array}{c}-1.04 \\
(-1.22 \text { to }-0.87)\end{array}$ & $\begin{array}{c}-0.63 \\
(-0.80 \text { to }-0.47)\end{array}$ \\
\hline $\begin{array}{l}\text { Growth hormone dosage, } \\
\mathrm{mg} / \mathrm{kg} \text { per wk }\end{array}$ & $\begin{array}{c}0.27 \\
(0.26 \text { to } 0.27)\end{array}$ & $\begin{array}{c}0.22 \\
(0.21 \text { to } 0.22)\end{array}$ & $\begin{array}{c}0.25 \\
(0.24 \text { to } 0.25)\end{array}$ & $\begin{array}{c}0.32 \\
(0.31 \text { to } 0.32)\end{array}$ & $\begin{array}{c}0.33 \\
(0.32 \text { to } 0.34)\end{array}$ \\
\hline $\begin{array}{l}\text { Stimulated peak growth } \\
\text { hormone level, } \mu \mathrm{g} / \mathrm{L}\end{array}$ & $\begin{array}{c}9.46 \\
\text { (9.18 to } 9.74)\end{array}$ & $\begin{array}{c}4.18 \\
(3.80 \text { to } 4.55)\end{array}$ & $\begin{array}{c}8.26 \\
\text { (7.95 to } 8.57)\end{array}$ & $\begin{array}{c}14.06 \\
(12.50 \text { to } 15.61)\end{array}$ & $\begin{array}{c}16.49 \\
(15.51 \text { to } 17.47)\end{array}$ \\
\hline \multicolumn{6}{|l|}{ Near-adult height } \\
\hline Age, yr & $\begin{array}{c}17.3 \\
(17.2 \text { to } 17.3)\end{array}$ & $\begin{array}{c}18.0 \\
\text { (17.8 to } 18.2)\end{array}$ & $\begin{array}{c}17.2 \\
(17.1 \text { to } 17.3)\end{array}$ & $\begin{array}{c}17.1 \\
(16.9 \text { to } 17.3)\end{array}$ & $\begin{array}{c}17.2 \\
(17.0 \text { to } 17.4)\end{array}$ \\
\hline Height SDS & $\begin{array}{c}-1.18 \\
(-1.21 \text { to }-1.15)\end{array}$ & $\begin{array}{c}-0.80 \\
(-0.90 \text { to }-0.69)\end{array}$ & $\begin{array}{c}-1.01 \\
(-1.05 \text { to }-0.97)\end{array}$ & $\begin{array}{c}-1.70 \\
(-1.77 \text { to }-1.63)\end{array}$ & $\begin{array}{c}-1.26 \\
(-1.34 \text { to }-1.18)\end{array}$ \\
\hline $\begin{array}{l}\text { Near-adult height SDS less } \\
\text { baseline height SDS }\end{array}$ & $\begin{array}{c}1.24 \\
(1.21 \text { to } 1.27)\end{array}$ & $\begin{array}{c}1.46 \\
\text { (1.35 to } 1.58)\end{array}$ & $\begin{array}{c}1.37 \\
(1.33 \text { to } 1.41)\end{array}$ & $\begin{array}{c}0.95 \\
(0.89 \text { to } 1.01)\end{array}$ & $\begin{array}{c}1.10 \\
(1.02 \text { to } 1.19)\end{array}$ \\
\hline Target height SDS deficit† & $\begin{array}{c}-0.76 \\
(-0.79 \text { to }-0.77)\end{array}$ & $\begin{array}{c}-0.73 \\
(-0.83 \text { to }-0.62)\end{array}$ & $\begin{array}{c}-0.43 \\
(-0.47 \text { to }-0.39)\end{array}$ & $\begin{array}{c}-1.74 \\
(-1.81 \text { to }-1.66)\end{array}$ & $\begin{array}{c}-0.60 \\
(-0.70 \text { to }-0.51)\end{array}$ \\
\hline $\begin{array}{l}\text { Growth hormone therapy } \\
\text { duration, yr }\end{array}$ & $\begin{array}{c}5.82 \\
(5.72 \text { to } 5.91)\end{array}$ & $\begin{array}{c}7.59 \\
\text { (7.26 to } 7.91)\end{array}$ & $\begin{array}{c}5.51 \\
(5.37 \text { to } 5.64)\end{array}$ & $\begin{array}{c}6.38 \\
\text { (6.12 to } 6.63)\end{array}$ & $\begin{array}{c}4.67 \\
(4.44 \text { to } 4.91)\end{array}$ \\
\hline $\begin{array}{l}\text { Last growth hormone } \\
\text { dosage, } \mathrm{mg} / \mathrm{kg} \text { per wk }\end{array}$ & $\begin{array}{c}0.28 \\
(0.28 \text { to } 0.28)\end{array}$ & $\begin{array}{c}0.20 \\
(0.19 \text { to } 0.21)\end{array}$ & $\begin{array}{c}0.27 \\
(0.26 \text { to } 0.27)\end{array}$ & $\begin{array}{c}0.32 \\
(0.31 \text { to } 0.33)\end{array}$ & $\begin{array}{c}0.36 \\
(0.35 \text { to } 0.37)\end{array}$ \\
\hline $\begin{array}{l}\text { Near-adult height SDS } \\
>-2.0, \text { no. }(\%)\end{array}$ & 81 & 84 & 86 & 66 & 82 \\
\hline
\end{tabular}

The majority of patients $(61.9 \%$ in Canada, $63.0 \%$ globally and $52.9 \%$ in the US) had growth hormone deficiency. However, the proportions with organic growth hormone deficiency $(44.6 \%, 13.3 \%$ and $10.9 \%$, respectively) versus idiopathic growth hormone deficiency $(17.3 \%, 49.5 \%$ and $41.7 \%$, respectively) reflected a higher frequency of inclusion in Canada of patients with abnormal pituitary development and intracranial tumour. The proportion of patients with Turner syndrome was also higher in Canada than in the global and US cohorts (18.4\%, $8.5 \%$ and $7.5 \%$, respectively), which may, in part, have been attributable to enrolment in GeNeSIS of patients from a large Canadian clinical trial. ${ }^{4}$ In addition, fewer patients in Canada than in the US had idiopathic short stature or were born small for gestational age. This likely indicates a more conservative approach of endocrine specialists in Canada to administering growth hormone to children with conditions not due to growth hormone deficiency, with the exception of Turner syndrome. Also, treatment of children with idiopathic short stature and those born small for gestational age is privately funded in many provinces in Canada, whereas growth hormone deficiency is fully reimbursed by provincial health insurance programs.

Patients showed increased height velocity SDS within the first year, with a positive mean value maintained over the first 


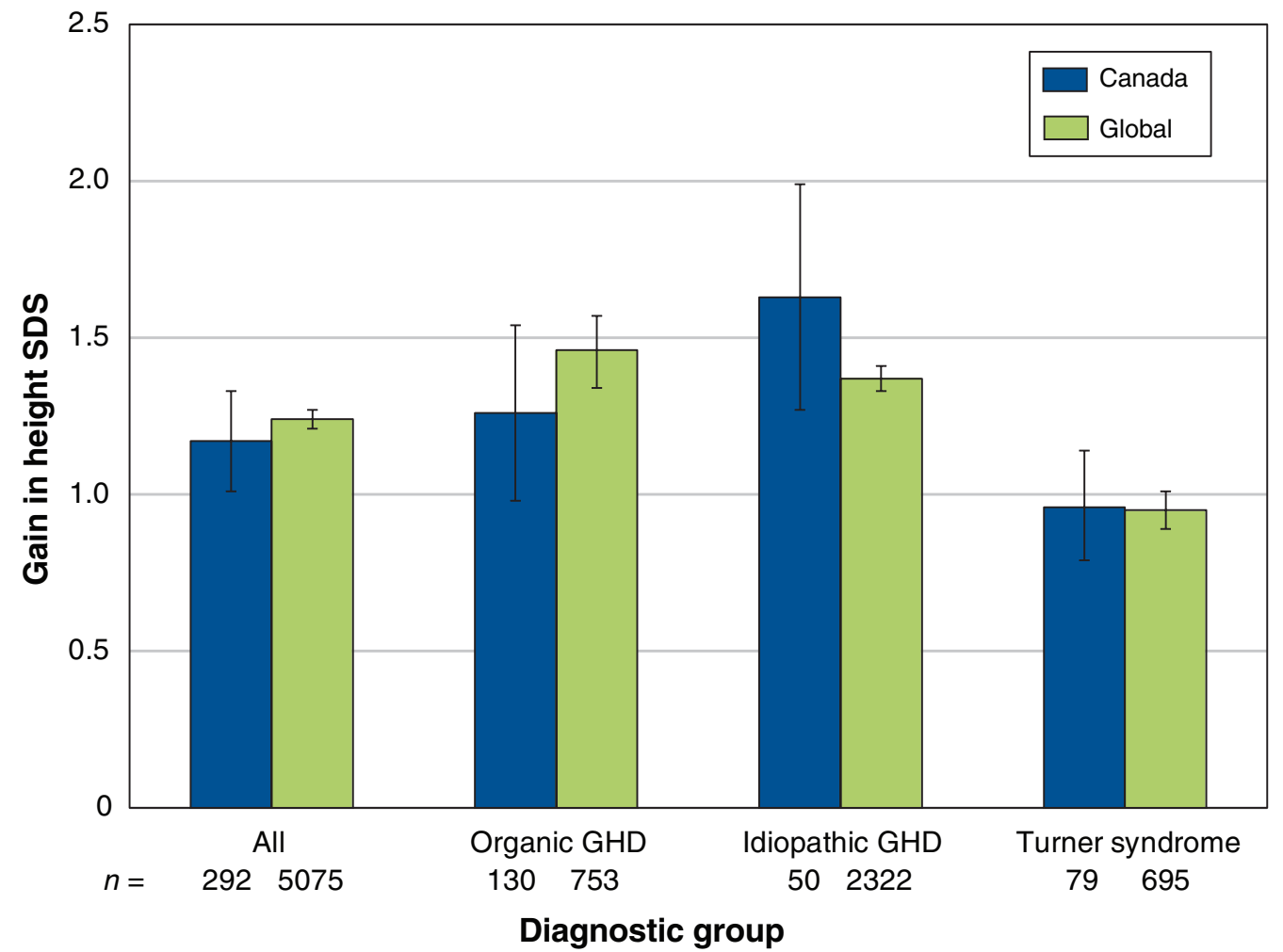

Figure 2: Change in height standard deviation score (SDS) from baseline to near-adult height for all growth-hormone-treated patients and by diagnostic group in Canada and the global population. Data for patients with idiopathic short stature are not shown because of the small number of patients $(n=10)$ in this diagnostic group in Canada with relevant data. Error bars $=95 \%$ confidence intervals. Note: GHD $=$ growth hormone deficiency.

3-4 years of growth hormone treatment, resulting in an increase in height SDS over time. Across all indications, growth response in the Canadian cohort was lower than that seen in the global cohort. Potential explanations for the differences in growth hormone response include the more conservative approach to treatment dosages in Canada than in the global, and particularly the US, populations, and the inclusion of milder or transient forms of growth hormone deficiency in the global cohort compared to a more severely affected group of patients in Canada.

Canadian patients with Turner syndrome were shorter than the global cohort at near-adult height, and proportions with near-adult height SDS within the normal range were lower than global proportions. This finding is consistent with past research showing near-adult height to be influenced by age at the start of growth hormone treatment, growth hormone dosage and concomitant estrogen treatment. ${ }^{6,35-37}$ However, patients with Turner syndrome in Canada had a similar gain in height SDS from baseline to near-adult height as the global cohort, at 0.96 . This gain was consistent with the results from the Canadian randomized clinical trial and other studies of growth hormone treatment in Turner syndrome. ${ }^{4,538}$ The tendency of Canadian physicians to treat shorter patients with Turner syndrome may reflect parent/ patient health care priorities, ${ }^{37}$ although the impact of provincial funding decisions may also play a role.

Treatment-emergent adverse events were reported more frequently among Canadian patients than among the global population $(70.5 \%$ v. $30.1 \%)$, which suggests that physicians in Canada may be more vigilant in reporting adverse events than physicians in other countries. Indeed, the Canadian cohort was the second-largest contributor of adverse events to the global database, surpassed only by the Netherlands, a country with an established national registry. With a mean treatment duration of 6.6 years, $11(1.3 \%)$ of the 850 Canadian patients were reported to have died (standardized mortality ratio 3.0 [95\% CI 1.5 to 5.4$]$ ). This was a higher frequency of death than that reported among the 21106 patients in the global cohort with follow-up in study and known sex, who were treated for a mean of 5.0 years (42 deaths [0.2\%]). ${ }^{21}$ The Canadian cohort included a higher proportion of patients with organic growth hormone deficiency (particularly with a history of intracranial tumour) than the global cohort. Of the 11 reported deaths, 7 were of children with a primary diagnosis of organic growth hormone deficiency; 4 of the 7 died because of cancer recurrence, and 1 patient previously treated 
Table 4: Serious and treatment-emergent adverse events reported in Canada

\begin{tabular}{|c|c|c|c|c|c|c|}
\hline \multirow[b]{2}{*}{ Adverse event } & \multicolumn{6}{|c|}{ Diagnostic category; no. (\%) of patients who reported adverse event } \\
\hline & All patients & $\begin{array}{c}\text { Organic } \\
\text { growth } \\
\text { hormone } \\
\text { deficiency }\end{array}$ & $\begin{array}{l}\text { Idiopathic } \\
\text { growth } \\
\text { hormone } \\
\text { deficiency }\end{array}$ & $\begin{array}{l}\text { Turner } \\
\text { syndrome }\end{array}$ & $\begin{array}{l}\text { Idiopathic } \\
\text { short stature }\end{array}$ & $\begin{array}{l}\text { Small for } \\
\text { gestational } \\
\text { age }\end{array}$ \\
\hline All patients & $n=850$ & $n=379$ & $n=147$ & $n=156$ & $n=38$ & $n=19$ \\
\hline Death* & $11(1.3)$ & $7(1.8)$ & $0(0.0)$ & $1(0.6)$ & $0(0.0)$ & $0(0.0)$ \\
\hline $\begin{array}{l}\text { Considered related to growth } \\
\text { hormone treatment } †\end{array}$ & $2(0.2)$ & $2(0.5)$ & $0(0.0)$ & $0(0.0)$ & $0(0.0)$ & $0(0.0)$ \\
\hline Serious adverse event & $97(11.4)$ & $61(16.1)$ & $7(4.8)$ & $9(5.8)$ & $3(7.9)$ & $1(5.3)$ \\
\hline $\begin{array}{l}\text { Considered related to growth } \\
\text { hormone treatment } \ddagger\end{array}$ & $19(2.2)$ & $12(3.2)$ & $1(0.7)$ & $4(2.6)$ & $2(5.3)$ & $0(0.0)$ \\
\hline Patients with $\geq 1$ follow-up visit & $n=833$ & $n=377$ & $n=137$ & $n=153$ & $n=38$ & $n=19$ \\
\hline$\geq 1$ treatment-emergent adverse event§ & $587(70.5)$ & $299(79.3)$ & $72(52.6)$ & $108(70.6)$ & $21(55.3)$ & $13(68.4)$ \\
\hline Headache & $88(10.6)$ & $55(14.6)$ & $12(8.8)$ & $9(5.9)$ & $2(5.3)$ & $3(15.8)$ \\
\hline Secondary hypothyroidism & $60(7.2)$ & $45(11.9)$ & $6(4.4)$ & $1(0.6)$ & $0(0.0)$ & $0(0.0)$ \\
\hline Scoliosis & $54(6.5)$ & $22(5.8)$ & $10(7.3)$ & $12(7.8)$ & $0(0.0)$ & $3(15.8)$ \\
\hline Ovarian failure & $50(6.0)$ & $9(2.4)$ & $0(0.0)$ & $41(26.8)$ & $0(0.0)$ & $0(0.0)$ \\
\hline Arthralgia & $48(5.8)$ & $16(4.2)$ & $5(3.6)$ & $13(8.5)$ & $1(2.6)$ & $1(5.3)$ \\
\hline Upper respiratory tract infection & $44(5.3)$ & $31(8.2)$ & $5(3.6)$ & $6(3.9)$ & $0(0.0)$ & $1(5.3)$ \\
\hline Hypothyroidism & $42(5.0)$ & $29(7.7)$ & $4(2.9)$ & $8(5.2)$ & $0(0.0)$ & $0(0.0)$ \\
\hline $\begin{array}{l}\text { Adverse event considered related to } \\
\text { growth hormone treatment }\end{array}$ & $87(10.4)$ & $48(12.7)$ & $6(4.4)$ & $18(11.8)$ & $3(7.9)$ & $2(10.5)$ \\
\hline Headache & $19(2.3)$ & $16(4.2)$ & $0(0.0)$ & $2(1.3)$ & $0(0.0)$ & $1(5.3)$ \\
\hline Scoliosis & $10(1.2)$ & $9(2.4)$ & $1(0.7)$ & $0(0.0)$ & $0(0.0)$ & $0(0.0)$ \\
\hline Arthralgia & $9(1.1)$ & $4(1.1)$ & $0(0.0)$ & $3(2.0)$ & $0(0.0)$ & $0(0.0)$ \\
\hline $\begin{array}{l}\text { Increase in insulin-like growth } \\
\text { factor level }\end{array}$ & $9(1.1)$ & $0(0.0)$ & $0(0.0)$ & $5(3.3)$ & $0(0.0)$ & $1(5.3)$ \\
\hline Melanocytic nevus & $7(0.8)$ & $4(1.1)$ & $0(0.0)$ & $3(2.0)$ & $0(0.0)$ & $0(0.0)$ \\
\hline Otitis media & $6(0.7)$ & $4(1.1)$ & $0(0.0)$ & $2(1.3)$ & $0(0.0)$ & $0(0.0)$ \\
\hline \multicolumn{7}{|c|}{$\begin{array}{l}\text { *See Supplementary Table A2, Appendix } 1 \text { for details. } \\
\text { †Both due to recurrence of medulloblastoma. } \\
\text { †All serious adverse events considered related to growth hormone treatment occurred in single patients except for medulloblastoma recurrence in } 2 \text { patients (both with } \\
\text { organic growth hormone deficiency) and adenoidal hypertrophy in } 2 \text { patients ( } 1 \text { with organic growth hormone deficiency, } 1 \text { with Turner syndrome). Other serious adverse } \\
\text { events reported as related to growth hormone treatment were meningioma, neoplasm progression, aortic valve incompetence, rectal hemorrhage, edema, death, parotitis, } \\
\text { upper limb fracture, type } 1 \text { diabetes mellitus, optic glioma, anaplastic astrocytoma, adrenal neoplasm, increased intracranial pressure, ischemic stroke, tonsillar hypertrophy, } \\
\text { sleep apnea syndrome, scoliosis surgery, meningioma surgery, adenoidectomy and angiodysplasia; some patients experienced more than } 1 \text { event. } \\
\text { §Any treatment-emergent adverse event irrespective of relatedness with frequency of } 5 \% \text { or more among all patients. } \\
\text { ๆAny treatment-emergent adverse event considered related with frequency greater than } 0.5 \% \text { among all patients. }\end{array}$} \\
\hline
\end{tabular}

with cranial irradiation died because of a second cancer. Analyses from various studies have indicated an increased risk of death in patients previously treated for malignant disease, irrespective of growth hormone treatment..$^{21,39-42}$ Results from the Childhood Cancer Survivor Study indicate no association of death or tumour recurrence with growth hormone treatment, ${ }^{42}$ which supports the assessment that these deaths were unlikely to be related to growth hormone treatment. Nevertheless, 3 of the deaths ( 2 recurrences of medulloblastoma and 1 anaplastic astrocytoma recurrence) were recorded by the investigators as being possibly related to growth hormone treatment; many investigators are cautious in assessing such events in the absence of defining factors and may state that a relation to growth hormone treatment cannot be ruled out, whereas others may reject the possibility of a causal relation based on temporal association or risk factors.

A previous analysis of GeNeSIS showed no increased risk for primary cancers during study participation in patients with no previous cancer history compared to general population cancer registries. ${ }^{16}$ Similarly, the US Pediatric Endocrine Society Drug and Therapeutics Committee found no association between growth hormone treatment and the risk of de novo cancer development in children with no prior history of or known predisposition to cancer. ${ }^{43}$ 
Analyses from the large Safety and Appropriateness of Growth hormone treatments in Europe (SAGhE) cohort showed an increased risk of death from several second malignant disorders in patients whose original diagnosis was cancer, ${ }^{44}$ with no clear raised risk in patients with growth failure without other major disease. Initial reports from the Childhood Cancer Survivor Study indicated that growth hormone treatment was associated with a higher relative risk for second neoplasms..$^{39,45}$ However, a more recent analysis of that study, with an extended period of follow-up, showed no direct evidence to support an increased risk of second neoplasms of the central nervous system in growth-hormone-treated patients, who clearly have risk factors other than growth hormone for development of subsequent neoplasms. ${ }^{42}$ Our observational study cannot resolve this question, but the balance of evidence suggests that the risk of malignant disease relates to the underlying condition rather than to growth hormone treatment.

\section{Limitations}

This analysis of Canadian data from GeNeSIS is limited in that the study was open-label and observational; however, the data reflect the real-world clinical setting of growth hormone treatment for a large patient cohort. In addition, biases are possible because of missing or incorrect reporting of data.

\section{Conclusion}

This study of growth-hormone-treated Canadian children, followed in an observational setting, showed that the major indication for growth hormone treatment in Canada is organic growth hormone deficiency. Overall effectiveness and safety results were generally consistent with those from other clinical trials and international surveillance databases. About $80 \%$ of patients with organic growth hormone deficiency or idiopathic growth hormone deficiency achieved a near-adult height within the normal range despite use of a lower dosage of growth hormone than that used in the global GeNeSIS population; smaller proportions of children with conditions not due to growth hormone deficiency achieved near-adult height within the normal range. The 11 reported deaths generally reflected the serious underlying cause of growth hormone deficiency. Although the current approach to growth hormone treatment in Canada is more conservative than some other global practices, it appears efficacious and safe. However - as per international guidelines ${ }^{13}$ - continued monitoring of patients previously treated with growth hormone is recommended.

\section{References}

1. Haymond MH, Kappelgaard AM, Czernichow P, et al.; Global Advisory Panel Meeting on the Effects of Growth Hormone. Early recognition of growth abnormalities permitting early intervention. Acta Paediatr 2013;102:787-96.

2. Audí L, Fernández-Cancio M, Camats N, et al. Growth hormone deficiency: an update. Minerva Endocrinol 2013;38:1-16.

3. Deal C, Hasselmann C, Pfäffle RW, et al. Associations between pituitary imaging abnormalities and clinical and biochemical phenotypes in children with congenital growth hormone deficiency: data from an international observational study. Horm Res Paediatr 2013;79:283-92.

4. Stephure DK; Canadian Growth Hormone Advisory Committee. Impact of growth hormone supplementation on adult height in Turner syndrome: results of the Canadian randomized controlled trial. 7 Clin Endocrinol Metab 2005;90: 3360-6.

5. Benabbad I, Rosilio M, Child CJ, et al. Safety outcomes and near-adult height gain of growth hormone-treated children with SHOX deficiency: data from an observational study and a clinical trial. Horm Res Paediatr 2017;87:42-50.

6. Kappelgaard AM, Laursen T. The benefits of growth hormone therapy in patients with Turner syndrome, Noonan syndrome and children born small for gestational age. Growth Horm IGF Res 2011;21:305-13.

7. Deal CL, Tony M, Höybye C, et al.; 2011 Growth Hormone in Prader-Willi Syndrome Clinical Care Guidelines Workshop Participants. Growth Hormone Research Society workshop summary: consensus guidelines for recombinant growth hormone therapy in Prader-Willi syndrome. 7 Clin Endocrinol Metab 2013;98:E1072-87.

8. Jung H, Rosilio M, Blum WF, et al. Growth hormone treatment for short stature in children born small for gestational age. Adv Ther 2008;25:951-78.

9. Hodson EM, Willis NS, Craig JC. Growth hormone for children with chronic kidney disease. Cochrane Database Syst Rev 2012;(2):CD003264.

10. Deodati A, Cianfarani S. Impact of growth hormone therapy on adult height of children with idiopathic short stature: systematic review. BMF 2011;342:c7157.

11. Loche S, Carta L, Ibba A, et al. Growth hormone treatment in non-growth hormone-deficient children. Ann Pediatr Endocrinol Metab 2014;19:1-7.

12. Sävendahl L, Maes M, Albertsson-Wikland K, et al. Long-term mortality and causes of death in isolated GHD, ISS, and SGA patients treated with recombinant growth hormone during childhood in Belgium, the Netherlands, and Sweden: preliminary report of 3 countries participating in the EU SAGhE study. 7 Clin Endocrinol Metab 2012;97:E213-7.

13. Allen DB, Backeljauw P, Bidlingmaier M, et al. GH safety workshop position paper: a critical appraisal of recombinant human GH therapy in children and adults. Eur 7 Endocrinol 2016;174:1-9.

14. Growth Hormone Research Society. Consensus guidelines for the diagnosis and treatment of growth hormone $(\mathrm{GH})$ deficiency in childhood and adolescence: summary statement of the GH Research Society. 7 Clin Endocrinol Metab 2000;85:3990-3.

15. Bell J, Parker KL, Swinford RD, et al. Long-term safety of recombinant human growth hormone in children. 7 Clin Endocrinol Metab 2010;95:167-77.

16. Child CJ, Zimmermann AG, Jia N, et al. Assessment of primary cancer incidence in growth hormone-treated children: comparison of a multinational prospective observational study with population databases. Horm Res Paediatr 2016;85:198-206.

17. Wilton P, Mattsson AF, Darendeliler F. Growth hormone treatment in children is not associated with an increase in the incidence of cancer: experience from KIGS (Pfizer International Growth Database). 7 Pediatr 2010;157: 265-70.

18. Sävendahl L, Pournara E, Pedersen BT, et al. Is safety of childhood growth hormone therapy related to dose? Data from a large observational study. Eur 7 Endocrinol 2016;174:681-91.

19. Ranke MB, Lindberg A, Tanaka T, et al. Baseline characteristics and gender differences in prepubertal children treated with growth hormone in Europe, USA, and Japan: 25 years' KIGS experience® (1987-2012) and review. Horm Res Paediatr 2017;87:30-41.

20. Wyatt D. Lessons from the National Cooperative Study. Eur 7 Endocrinol 2004;151(Suppl 1):S55-9.

21. Quigley CA, Child CJ, Zimmerman AG, et al. Mortality in children receiving growth hormone treatment of growth disorders: data from the Genetics and Neuroendocrinology of Short Stature International Study. 7 Clin Endocrinol Metab 2017;102:3195-205.

22. Guyda H, Friesen H, Bailey JD, et al. Medical Research Council of Canada therapeutic trial of human growth hormone: first 5 years of therapy. Can Med Assoc 7 1975;112:1301-9.

23. Taback SP, Dean HJ. Mortality in Canadian children with growth hormone (GH) deficiency receiving GH therapy 1967-1992. The Canadian Growth Hormone Advisory Committee. 7 Clin Endocrinol Metab 1996;81:1693-6.

24. Guyda H, Dean H. Intermittent GH administration in growth hormone deficiency. In: Laron Z, Butenault O, Raiti S, editors. Clinical use of growth bormone: present and future aspects. Proceedings of the 2 nd meeting of the International Growth and Development Association (IGDA), Taormina on Sea; May 1986. New York: S. Karger; 1987:1661-71.

25. Cappa M, Iughetti L, Loche S, et al.; GeNeSIS National Board on behalf of the GeNeSIS Italian Investigators. Efficacy and safety of growth hormone treatment in children with short stature: the Italian cohort of the GeNeSIS clinical study. F Endocrinol Invest 2016;39:667-77.

26. Luzuriaga Tomás C, Oyarzabal Irigoyen M, Caveda Cepas E, et al.; el grupo de investigadores españoles del estudio GeNeSIS. Safety and efficacy of growth hormone treatment: GeNeSIS study in Spain [article in Spanish]. An Pediatr (Barc) 2016;84:139-47.

27. Tai S, Tanaka T, Hasegawa T, et al. An observational study of the effectiveness and safety of growth hormone (Humatrope(®)) treatment in Japanese children with growth hormone deficiency or Turner syndrome. Endocr 7 2013;60:57-64.

28. Fujieda K, Tanaka T, Takano K, et al.; KIGS Japan Scientific Committee. Adult height after growth hormone treatment in Japanese children with idiopathic growth hormone deficiency: analysis from the KIGS Japan database. 7 Pediatr Endocrinol Metab 2011;24:457-62. 
29. Cohen P, Rogol AD, Deal CL, et al.; 2007 ISS Consensus Workshop participants. Consensus statement on the diagnosis and treatment of children with idiopathic short stature: a summary of the Growth Hormone Research Society, the Lawson Wilkins Pediatric Endocrine Society, and the European Society for Paediatric Endocrinology Workshop. 7 Clin Endocrinol Metab 2008;93: 4210-7.

30. Ogden CL, Kuczmarski RJ, Flegal KM, et al. Centers for Disease Control and Prevention 2000 growth charts for the United States: improvements to the 1977 National Center for Health Statistics version. Pediatrics 2002;109:45-60.

31. Preece MA. Evaluation of growth and development. In: Holliday MA, Barratt TM, Avner ED, et al., editors. Pediatric nephrology. 3rd ed. Baltimore: Williams \& Wilkins;1994:378-96.

32. Marshall WA, Tanner JM. Variations in the pattern of pubertal changes in boys. Arch Dis Child 1970;45:13-23.

33. Marshall WA, Tanner JM. Variations in pattern of pubertal changes in girls. Arch Dis Child 1969;44:291-303.

34. Guidance documents for industry - reporting adverse reactions to marketed health products. Ottawa: Health Canada; 2011. Available: https://www.canada.ca/ en/health-canada/services/drugs-health-products/reports-publications/medeffect -canada/guidance-document-industry-reporting-adverse-reactions-marketed-health -products-health-canada-2011.html (accessed 2017 Sept. 7).

35. Ross JL, Quigley CA, Cao D, et al. Growth hormone plus childhood low-dose estrogen in Turner's syndrome. N Engl f Med 2011;364:1230-42.

36. Chernausek SD, Attie KM, Cara JF, et al. Growth hormone therapy of Turner syndrome: the impact of age of estrogen replacement on final height. Genentech, Inc., Collaborative Study Group. $\mathcal{F}$ Clin Endocrinol Metab 2000;85: 2439-45.

37. Khatchadourian $\mathrm{K}$, Huot C, Alos N, et al. Impact of patient characteristics and clinical factors on the decision to initiate growth hormone treatment in Turner syndrome. Horm Res 2008;70:300-8.

38. Quigley CA, Crowe BJ, Anglin DG, et al. Growth hormone and low dose estrogen in Turner syndrome: results of a United States multi-center trial to near-final height. 7 Clin Endocrinol Metab 2002;87:2033-41.

39. Sklar CA, Mertens AC, Mitby $\mathrm{P}$, et al. Risk of disease recurrence and second neoplasms in survivors of childhood cancer treated with growth hormone: a report from the Childhood Cancer Survivor Study. 7 Clin Endocrinol Metab 2002;87:3136-41.

40. Berglund A, Gravholt CH, Olsen MS, et al. Growth hormone replacement does not increase mortality in patients with childhood-onset growth hormone deficiency. Clin Endocrinol (Oxf) 2015;83:677-83.

41. Packer RJ, Boyett JM, Janss AJ, et al. Growth hormone replacement therapy in children with medulloblastoma: use and effect on tumor control. 7 Clin Oncol 2001;19:480-7.

42. Patterson BC, Chen Y, Sklar CA, et al. Growth hormone exposure as a risk factor for the development of subsequent neoplasms of the central nervous system: a report from the Childhood Cancer Survivor Study. 7 Clin Endocrinol Metab 2014;99:2030-7.

43. Raman S, Grimberg A, Waguespack SG, et al. Risk of neoplasia in pediatric patients receiving growth hormone therapy - a report from the Pediatric Endocrine Society Drug and Therapeutics Committee. 7 Clin Endocrinol Metab 2015;100:2192-203.

44. Swerdlow AJ, Cooke R, Beckers D, et al. Cancer risks in patients treated with growth hormone in childhood: the SAGhE European cohort study. 7 Clin Endocrinol Metab 2017;102:1661-72.

45. Ergun-Longmire B, Mertens AC, Mitby P, et al. Growth hormone treatment and risk of second neoplasms in the childhood cancer survivor. 7 Clin Endocrinol Metab 2006;91:3494-8.

Competing interests: Cheri Deal has been involved with phase III and/ or phase IV studies with Eli Lilly and Company, Serono, Versartis and OPKO Health, invited lectureships sponsored by Novo Nordisk, Eli Lilly and Company, Pfizer, EMD Serono and Merck Serono, ad hoc consulting with EMD Serono, Novo Nordisk, Merck Serono, Versartis, OPKO Health and Zafgen, and the Grant for Growth Innovation Scientific Advisory Board: Merck. She was a member of the Genetics and Neuroendo- crinology of Short Stature International Study International Advisory Board. She has received honoraria and meeting expenses from Eli Lilly and Company. Susan Kirsch and Nan Jia are employees of Eli Lilly and Company. Jean-Pierre Chanoine has received honoraria (speaker fees and advisory board membership) from Eli Lilly and Company. Elizabeth Cummings has received grant support from Eli Lilly and Company and Sanofi. Elizabeth Rosolowsky has received grant support from Eli Lilly and Company and has served on the advisory boards for Insulet and Medtronic. Christopher Child is an employee and stockholder of Eli Lilly and Company. No other competing interests were declared.

Affiliations: University of Montreal and Centre hospitalier universitaire Sainte-Justine (Deal), Montréal, Que.; Lilly Research Laboratories (Kirsch), Toronto, Ont.; Endocrinology and Diabetes Unit (Chanoine), British Columbia Children's Hospital, Vancouver, BC; Division of Endocrinology and Metabolism (Lawrence), Children's Hospital of Eastern Ontario, Ottawa, Ont.; Division of Endocrinology (Cummings), IWK Health Centre, Dalhousie University, Halifax, NS; Division of Endocrinology (Rosolowsky), Department of Pediatrics, University of Alberta, Edmonton Clinic Health Academy, Edmonton, Alta.; Department of Pediatrics and Child Health (Marks), Children's Hospital Health Sciences Centre Winnipeg, University of Manitoba, Winnipeg, Man.; Lilly Research Laboratories (Jia), Indianapolis, Ind.; Eli Lilly and Company (Child), Windlesham, UK

Contributors: Cheri Deal, Susan Kirsch and Christopher Child were responsible for conceiving the project and drafting the manuscript. Cheri Deal, Susan Kirsch, Christopher Child, Jean-Pierre Chanoine, Elizabeth Cummings, Sarah Lawrence, Seth Marks and Elizabeth Rosolowsky were responsible for acquiring and interpreting the data. Christopher Child and Nan Jia were responsible for analyzing the data. All of the authors critically revised the manuscript for important intellectual content, gave final approval of the version to be published and agreed to be accountable for all aspects of the work.

Genetics and Neuroendocrinology of Short Stature International Study (GeNeSIS) Canada Investigators: Additional GeNeSIS investigators were Jill Hamilton (Hospital for Sick Children, Toronto, Ont.), Daniele Pacaud (Alberta Children's Hospital, Calgary, Alta.), Susan Sanderson (Saint John Regional Hospital Facility, Saint John, NB), Susan Stock (private practice, North Vancouver, BC), Cheril Clarson (Children's Hospital of Western Ontario, London, Ont.), Angelo Simone (private practice, Mississauga, Ont.), Shayne Taback (Children's Hospital Research Institute of Manitoba, Winnipeg, Man.), Laurent Legault (Montreal Children's Hospital, Montréal, Que.), Dardye Eugene (Centre hospitalier universitaire de Québec, Québec, Que.), Judith Simoneau-Roy (Centre hospitalier universitaire de Sherbrooke, Sherbrooke, Que.) and Tracey Bridger (Janeway Children's Health and Rehabilitation Centre, St. John's, Nfld.).

Funding: The Genetics and Neuroendocrinology of Short Stature International Study program was supported by Eli Lilly and Company.

Acknowledgements: Assistance with preparation and editorial review of the manuscript was provided by Peter Bates, Cambridge Medical Writing Services, UK, and Caroline Spencer, Rx Communications, UK, funded by Eli Lilly and Company.

Supplemental information: For reviewer comments and the original submission of this manuscript, please see www.cmajopen.ca/content/6/3/ E372/suppl/DC1. 